\title{
Flexible higher training in psychiatry
}

\author{
Attitudes and perceptions of flexible trainees
}

\author{
Anne Dean, Samaa El Abd and Ann York
}

\begin{abstract}
Alms and method This survey was commissioned and funded by the Department of Health to examine perceptions of training by flexible trainees in higher psychiatric training. A total of 214 trainees were surveyed using a postal questionnaire.

Results One hundred and thitty-five questionnaires were returned (response rate 63\%). In general, flexible trainees valued the opportunity to train part-time and percelved the quallty of their training to be high. However, there were drawbacks such as: percelved lack of status, restricted training opportunities and a lack of part-time consultant posts at the end of training. Implications Flexible training plays a major role in maintaining doctors in the workforce. However, there is a need for part-time opportunities to extend beyond the training grades and into consultant posts.
\end{abstract}

\section{The study}

The Department of Health commissioned the Royal College of Psychiatrists to survey the perceptions and attitudes of trainees working on a flexible basis in higher specialist training in psychiatry. Funding did not extend to full-time trainees.

Two flexible senior registrars based at St George's Hospital, London prepared a questionnaire which was then modified by a working group of the Education Committee of the Royal College of Psychiatrists. The 27 questions covered demography, reasons for, and perceptions of, flexble training and an open section for free comment (a copy can be obtained from A. D.).

The College's Department of Postgraduate Educational Services posted the questionnaire to all the 214 flexible trainees in higher training in psychiatry. A second postal reminder was sent to non-responders. Data analysis was undertaken by the College Research Unit and was completed on 13 May 1998.

\section{Findings}

After two mallings, 154 questionnaires were returned. One hundred and thirty-five were able to be analysed (63\%). In some cases, questions remained unanswered or the responses given were unclear, therefore a complete statistical breakdown was not possible for every question.

The responses received clearly indicated that the vast majority of those in flexible training were female, and that the main reason why a flexible option was chosen was due to domestic commitments. The mean length of time in flexible training was 2.7 years (s.d. 2.25, range 0-11 years). The mean number of sessions employed per week was six (s.d. 1.1, range 0-10). Sixty per cent of trainees stated that they worked an additional one to two unpaid sessions a week. A number of trainees indicated that they were seeking a dual Certificate of Completion of Specialist Training. Table 1 summarises the main findings of the structured part of the questionnaire.

All respondents were in favour of flexible and part-time working for consultants in psychiatry, and believed that far more opportunities should exist. Seventy per cent wanted to be employed in a part-time or flexible consultant post or were considering a job-share and for the majority $(66 \%)$ this was so that they could continue to care for their children.

The open section of the questionnaire revealed a variety of feelings and perceptions about flexible training. Overall, flexdble training was viewed as positive, but several suggestions were made for improvements (see Appendix).

\section{Comments and implications for training}

These perceptions of flexible trainees cannot be compared with those of full-time trainees as funding did not allow a similar survey of fulltime trainees. However, it is clear that flexible trainees value part-time training in psychiatry, although there are problems associated with working in this way. The quality of training is usually high, and offers the opportunity to combine work with domestic and family 
Table 1. Demographics and perceptions of flexible trainees about their training $(n=135)$

\begin{tabular}{|c|c|}
\hline & $\%$ \\
\hline Gender & 96 \\
\hline \multicolumn{2}{|l|}{ Reason for flexible training } \\
\hline Domestic commitments & 87 \\
\hline \multicolumn{2}{|l|}{ Training speciality } \\
\hline General adult & 45 \\
\hline Child and adolescent & 27 \\
\hline Psychotherapy & 7 \\
\hline Learning disability & 2 \\
\hline Forensic & 1 \\
\hline \multicolumn{2}{|l|}{ Current grade } \\
\hline Senior registrar & 72 \\
\hline Specialist registrar & 19 \\
\hline Lecturer & 1 \\
\hline Other & 3 \\
\hline \multicolumn{2}{|c|}{$\begin{array}{l}\text { In absence of flexible training posts, alternatives } \\
\text { chosen }\end{array}$} \\
\hline Full-time psychiatry & 40 \\
\hline Not work at all & 28 \\
\hline Non-medical work & 25 \\
\hline Another medical field & 24 \\
\hline General or private practice & 2 \\
\hline \multicolumn{2}{|l|}{ Flexible training is of real benefit } \\
\hline Agree & 93 \\
\hline $\begin{array}{l}\text { Flexible training enables the trc } \\
\text { their time }\end{array}$ & \\
\hline Agree & 67 \\
\hline \multicolumn{2}{|c|}{$\begin{array}{l}\text { Full-time training has higher status than flexible } \\
\text { training }\end{array}$} \\
\hline Agree & 67 \\
\hline \multicolumn{2}{|l|}{ Flexible training is too lengthy } \\
\hline Agree & 40 \\
\hline \multicolumn{2}{|c|}{$\begin{array}{l}\text { Compared to full-time training, the quality } \\
\text { of flexible training is }\end{array}$} \\
\hline Equivalent & 47 \\
\hline Better & 24 \\
\hline Worse & 23 \\
\hline
\end{tabular}

commitments, which is often not possible in other careers. Most importantly, it does appear that flexible training has kept medical graduates in the work force as in the absence of flexible training, $28 \%$ of trainees would have chosen not to work at all and $25 \%$ would have chosen nonmedical work. This major benefit was noted recently in the Thames region, where no trainees have been lost to medicine in the last three years or so (Goldberg, 1997).

Many findings in this study are similar to those of a recent survey of all the flexible trainees in the UK, not just those training in psychiatry (Norcliffe \& Finlan, 1999). There is also evidence that some senior medical staff, particularly men, view flexible training as inferior (NHS Management Executive, 1993). Perceptions of the flextble trainees in our survey about their status may be accurate, unfortunately.

A considerable number of disadvantages to flexible training were identified in this survey, mostly relating to perception of lack of status, inequity of training opportunities compared with full-time colleagues and restricted time available to find consultant posts at the end of training. Those surveyed unanimously agreed that more flexible posts at consultant level should be established.

\section{Acknowledgements}

Many thanks to Dr Richard Duffett, Clinical Research Fellow and Miss Catherine Ayres, Research Assistant at the College Research Unit who undertook the analysis of the results. Funding was provided by the Department of Health.

\section{References}

GOLDBERG. I. (1997) Flexible training in psychiatry. Psychiatric Bulletin, 21, 387-388.

NHS MANAGEMENT ExeCUTIVE (1993) Flexible Training: Report of the Joint Working Party. London: HMSO.

NORCLIFF, G. \& Finlan, C. (1999) Attitudes to flexdble training. British Medical Journal, $\mathbf{3 1 8}$ (classifled suppl. 13 March), 2-3.

\section{Appendix}

Summary of open comments made by trainees General:

(a) Individual training programmes are an excellent idea.

(b) The ability to combine work and family commitments is extremely valuable. Most other professions are a long way behind in this regard.

(c) Flexible training can be helpful in terms of learning time and self-management.

Training issues:

(a) Some trainees feel that they work harder, clinically and academically, than their full-time colleagues, and believe that they are doing a full-time job in part-time hours. Additional training (e.g. psychotherapy) often occurs in non-work time for flexible trainees but in work time for full-time trainees.

(b) Some trainees are not included in meetings/events arranged for full-time trainees. There can be practical difficulties when conferences, for example, occur in the non-working part of the week.

(c) Flexible trainees are regarded by some as 'second best'; one respondent stated that 
when she returned to full-time work she felt she had 'rejoined her colleagues'; another was asked by colleagues when the "proper full-time senior registrar" was starting work.

Financial issues:

(a) Flexible training has substantial financial disadvantages. Membership fees (e.g. those of the College) are rarely pro-rata and child care is an additional financial drain on a reduced salary.

\section{Suggestions made by trainees for improvements}

(a) Difficulties can be experienced in returning to work after a career break. A return to work' scheme would be helpful.

(b) True flexibility would allow for easier movement between career and non-career grade posts.

(c) Some flexible trainees are advised that, following obtaining their Certificate of
Completion of Specialist Training, they will be allowed the same time as full-time trainees (six months) to find a consultant post. This is considered to be iniquitous and that the time allowed should be prorata.

(d) The status of flexible training would rise if there were a rise in both male and female part-time consultant working practices.

*Anne Dean, Head of Postgraduate Educational Services, Royal College of Psychiatrists, 17 Belgrave Square, London SW1X 8PG; Samaa El Abd, Senior Registrar and Research Fellow in Child and Adolescent Psychiatry, and Ann York, Honorary Senior Lecturer and Consultant in Child and Adolescent Psychiatry. Department of General Psychiatry. Jenner Wing, St George's Hospital Medical School, Cranmer Terrace, London SW17 ORE

*Correspondence

\title{
Royal College of Psychiatrists
}

\section{TRAINING DAY IN ELECTROCONVULSIVE THERAPY}

\author{
King's Fund, Cavendish Square, London \\ Tuesday, 9th November 1999
}

The Royal College of Psychiatrists' Special Committee on Electroconvulsive Therapy is to offer another ECT Training Day at the King's Fund, London. The format will be a combination of presentations and participatory workshops. The Training Day will include sessions of particular interest to nurses and anaesthetists, as well as psychiatrists involved in ECT practice.

\section{A programme and booking form can be obtained from:}

Mrs A Fewings, Conference Office, Royal College of Psychiatrists, 17 Belgrave Square, London SWIX 8PG

Telephone +44 (0) 17| 2352351 ext. 142, Fax +44 (0) 171 2596507

E-mail: afewings@rcpsych.ac.uk 